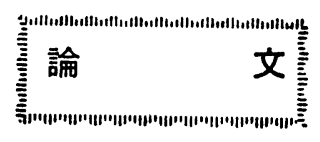

\title{
光源発光波形の商用電源周波数成分による ちらつき評価
}

\author{
正会員川上 幸 二* 小久保 哲夫* \\ Evaluation of Flicker by Analysing Harmonics of Light Output \\ Kohji Kawakami (Member), Tetsuo Kokubo \\ (IWASAKI Electric Co., LTD.)
}

\begin{abstract}
Light output of the ordinary discharge lamps operating on A. C. power supply shows cyclic variation similar to A. C. input power, and whose frequency is twice of the A. C. input power.

This variation of light output is called "FLICKER". "FLICKER INDEX" and "PERCENT FLICKER" have been proposed as ideas to evaluate the flicker of light sources. However, they cannot offen accurate evaluation of the flicker, because actual sensibility to the human eye may differ even if they have the same numerical values of evaluation measured under the same measuring conditions.

To increase accuracy of evaluation, "FLICKER BY DISTORTED WAVE" is introduced as new concept. This new method of evaluation is realized by checking the lower harmonic component after harmonic analysis of light output applying "FOURIER SERIES".

We recognize through our repeated experiments that the results evaluated by this "FLICKER BY DISORTED WAVE" are conformed to actual sensibility of flicker.
\end{abstract}

\section{1. ま え がき}

放電ランプなどが一般の商用電源で点灯される場合に，光源は その周波数（50または $60 \mathrm{~Hz}$ )の 2 倍の周波数で（高周波点灯を 除けば）発光を繰り返す，この結果として，光源自身のちらつき （フリッカ）が感じられたり，高速で動くテニスボールなどの視 対象がちらついて見えること（ストロボ効果）がある.

このようなちらつきの評価は，ストロボ効果よりもむしろ光源 の発光波形に着目したものが多く, フリッカインデックス $(\mathrm{FI})^{1}$ やパーセントフリッカ $(\mathrm{FP})^{1)}$ などが提案されている. しかしな がら、これらの評佂数が同じ值であり，観察条件も同一であるに もかかわらず，光源自身のちらつきが感じられたり感じなかった りする場合がある2)。このことは，これらの評侀法が必ずしも人 間の感覚と一致するとはかざらないことを示している. 一方, 腰 原らは光源発光波形の低周波成分が，ちらつきに拈いて重要な因 子であることを報告している3.

われわれは腰原らの考光に基づき，光源の発光波形が一種のひ ずみ波であると考光，発光周波数の $1 / 2$, すなわち商用電源周波 数 $(50$ または $60 \mathrm{~Hz})$ 成分をフーリエ級数により抽出し，これに よる評価値が人間の感覚とよく一致することを実験により見いだ した。

* 岩崎電気相

\section{2. ちらつきの評価法}

2.1 パーセントフリッカ法1

この方法は, 図 1 に示す発光波形モデル $y_{(t)}$ (実線)に打い て最大値 $A$ と最小值 $D$ 亿着目した評洒法であり(1)式にて求まる.

$$
P F=\frac{A-D}{A+D} \times 100
$$

ただし $P F$ ：パーセントフリッカ値, $A$ : 最大値, $D$ : 最小値 いま, $y_{(t)}$ の一部が図 1 の点線で示すように, $B$ 值が（B$\Delta b)$ 值に $C$ 值が $(C+\Delta C)$ 值に変化し, 平均値 $\left(A_{0}\right)$ が一定の ままであると仮定すれば，このときのパーセントフリッカ值は，

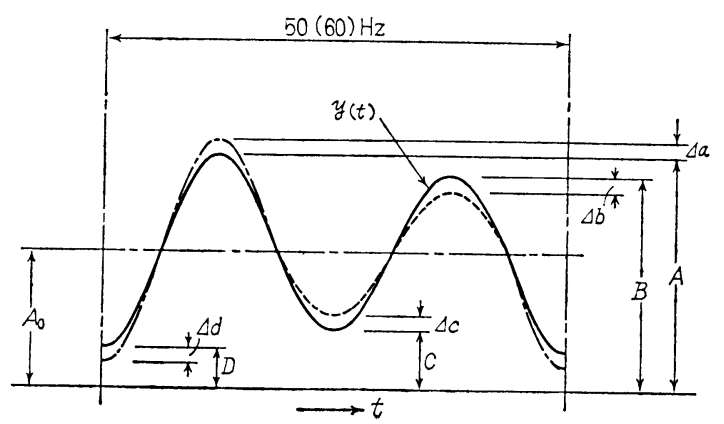

図 1 光源発光波形モデル 
$A$ 值およびD值がそのままであるので変化しない，しかし現実的 には腰原ら ${ }^{2)}$ が報告しているようにららつき感覚は変化する.す なわちパーセントフリッカ法では，このような相違を表わすこと ができないことになる.

\section{2 フリッカインデックス法 ${ }^{1)}$}

この方法は, 発光波形 $y_{(t)}$ の平均値を越兄る部分の積分值 (平 均を越觉る部分の面積) と平均值 (発光部分の面積) の比であ り，(2)式にて求まる.

$$
F I=\frac{\text { 面積 } I}{\text { 面積 } \mathrm{I}+\text { 面積 } I I}
$$

ただし 面積 I：平均值を越える部分の面積 面積 II : 平均値を下回る部分の面積

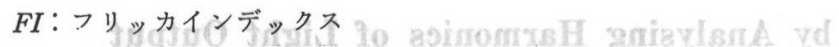

いま $y_{(t)}$ が図 1 の点線と一点鎖線で示すように, $A$ 值が $(A$ $+\Delta a)$ 值に, $B$ 值が $(B-\Delta b)$ 值に, $C$ 值が $(C+\Delta c)$ 值に, $D$ 值が $(D-\Delta d)$ 值に変化し, 平均值が一定のままであると仮 定すれば, フリッカインデックス值はほとんど変化しない。

すなわちフリッカインデックス法でも，このような相違によるATTPRA ちらつき感覚の差を表わすことができないことになる。

\section{3 提案する評価法}

一般にひずみ波交流 ${ }^{5)}$ は, フーリエ級数に展開でき(3)式に示す 時間の関数で表わすことができる.

$$
\begin{aligned}
y_{(t)} & =\sum_{n=0}^{\infty} A_{n} \cdot \sin \left(n \omega t+\varphi_{n}\right) \\
A_{0} & =\frac{1}{T} \int_{0}^{T} y(t) d t \\
A_{n} & =\left(a_{n}^{2}+b_{n}^{2}\right)^{1 / 2}
\end{aligned}
$$

$\tan \varphi_{n}=a_{n} / b_{n}$

$$
\begin{aligned}
& a_{n}=\frac{2}{T} \int_{0}^{T} y(t) \cdot \cos n \omega t \cdot d t \\
& b_{n}=\frac{2}{T} \int_{0}^{T} y(t) \cdot \sin n \omega t \cdot d t
\end{aligned}
$$

$$
\text { ただし， } \omega=2 \pi f \quad f=\frac{1}{T}
$$

われわれは, 発光波形 $y_{(t)}$ の基本周波数を 商用電源周波数 の $1 / 2\left(f^{\prime}=25 \mathrm{~Hz}\right.$ または $\left.f=30 \mathrm{~Hz}\right)$ 飞設定*し, その第 2 高調波 $(50$ または $60 \mathrm{~Hz})$ 成分が全体に占める割合によって, ちらつき を評価する方法を考案した．これを「ひずみ波フリッカ」と呼ぶ ものとし(4)式に示す.

$$
F_{(\mathrm{Hz})}=\frac{A_{2} / \sqrt{2}}{A_{0}} \times 100
$$

ただし， $A_{0}$ : 直流成分 (平均值), $A_{2}$ : 第 2 高調波 (商用周波 数成分), $F_{(\mathrm{H} 2)}$ : ひずみ波フリッカ值.

な技， $(\mathrm{Hz})$ 部分には商用電源周波数を示すものとし, $A_{2} / \sqrt{2}$ は第 2 高調波成分の実効值を表わす.

図 2は, 実際の光源発光波形とひずみ波フリッカ值を示した ものであり，形状の変化と評価值との対応が良いことがわかる. もし図2 (a)よりもひずみが少なくなれば, ひずみ波フリッカ值は 0 に近つくことになり, 発光波形は商用電源周波数の 2 倍（100

*フーリ工級数で商用周波数成分を抽出するには，基本周波数を整数倍した高調 波周波数と商用周波数とを一致させればよい。われわれは 3.1 項に示すように 測定を商用電源の 2 サイクルについて行ない,それに基づいて解析を行なった. このため, 解析の基本周波数を商用周波数の $1 / 2$ とし, 第 2 高調波が商用周波

数と一致するようにした.

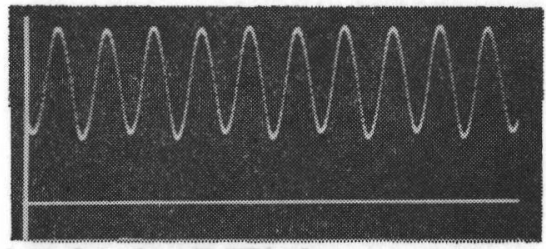

a. $F(50)=1.50 \quad \longrightarrow t$

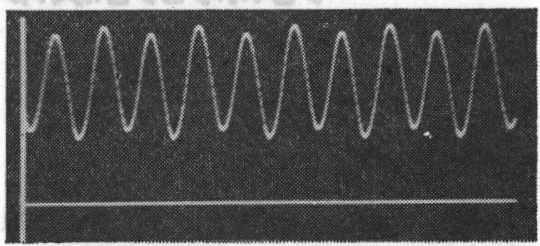

$$
\text { b. } F_{(50)}=3.48 \quad \longrightarrow t
$$

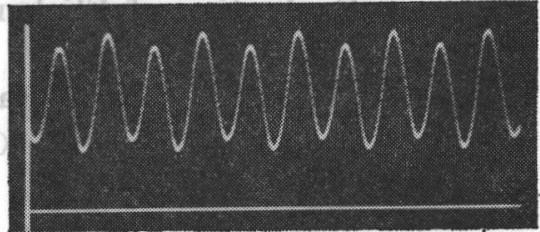

c. $F_{(50)}=5.10 \quad \longrightarrow t$

図 2 発光波形とひずみ波フリッカ值

または $120 \mathrm{~Hz}$ ）の規則正しい形状になる。このことは，臨界融 合周波数 $(\mathrm{CFF})^{4)}$ の研究からも明らかなように, 人間の目には ほとんど知覚できないことを示すことになる.

ひずみ波フリッカ值の簡易的な算出法として(5)式を用いること ができる.ただし(5)式は図 1 や図 2 に示すように電源波形の 1 周 期 $(50$ または $60 \mathrm{~Hz})$ に各々 2 回生じる発光波形の最大值だけが 相異するるのだけ適用すべきである.

$$
F_{(\mathrm{Hz})}=\frac{\sqrt{(A-B)^{2}+(C-D)^{2}} / \sqrt{2}}{(A+B+C+D) / 4} \times 100 \cdots \cdots \cdots(5)
$$

一方, $50 \mathrm{~Hz}$ と $60 \mathrm{~Hz}$ に和けるひずみ波フリッカ值は, 発光波 形が時間軸 $(t)$ に対して相似形である場合には, $F_{(50)}=F_{(60)}$ の 関係が成立する.

\section{3. 実験}

ひずみ波フリッカ值と人間の感覚量との問に相関関係が存在す るか否か, すなわちひずみ波フリッカ法が妥当であるかどらかを 検証することを目的に以下に示す実験を行なった。

実験に際して, ちらつき知覚に関する CFF の研究4を参考に した. CFF は主に周波数に関係しているのに対し，われわれの ひずみ波フリッカは, 発光波形のひずみに関係している点で異な る. しかし CFF の研究から明らかにされた視覚生理あるいは視 覚心理は,ひずみ波に基づくららつき現象を知覚の面から検討す るに際して, 参考になるものと思われるので, その要点を次に示 して扰く.

(1) 検査光の輝度が高くなるにつれて，CFF は上昇する（Ferry-Poter の法則).

(2) 検査光の見かけの大きさが増すにつれて，CFF は上昇する (Granit-Harper の法則).

(3) 網膜位置によって CFF が異なり，これは輝度および見か けの大きさによって複雑に変化する.

(4) CFF は, 個人差, 年齿, 疲労, ストレスなどの影響を受 ける. 


\section{1 装置}

評価実験に用いた装置を図 3 に示す, 前面アクリルパネルの 発光部分の大きさは口 $900 \mathrm{~mm}$ であり, 被験者はその面より約 300 $\mathrm{mm}$ 以内の中心に位置する. したがって被験者の視野の大半 (半 径約 $\left.55^{\circ}\right)$ はパネル面で占められることになり, 網膜位置に関係 したセらつき感覚の相違が汪湾解消できるものと考えられる.

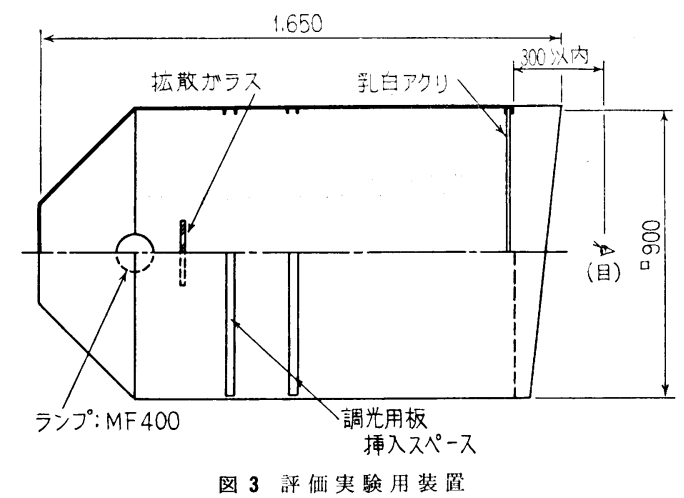

パネル面の輝度調節は, 調光用板挿入スペースに, 障子紙, ケ ント紙, アクリル (半乳), パンチングメタル（孔の大小で 2 種 類）を単独あるいは組み合わせて插入して行なら方法とした．図 4 は調光用板を插入しない場合のパネル面の楎度分布であり, 各 調光段階に打いても同程度の均斉度が得られている。なお光源は メタルハライドランプ $400 \mathrm{~W}$ （MF 400, 相関色温度約 $3800 \mathrm{~K}$ ) とし水平点灯で用いた。
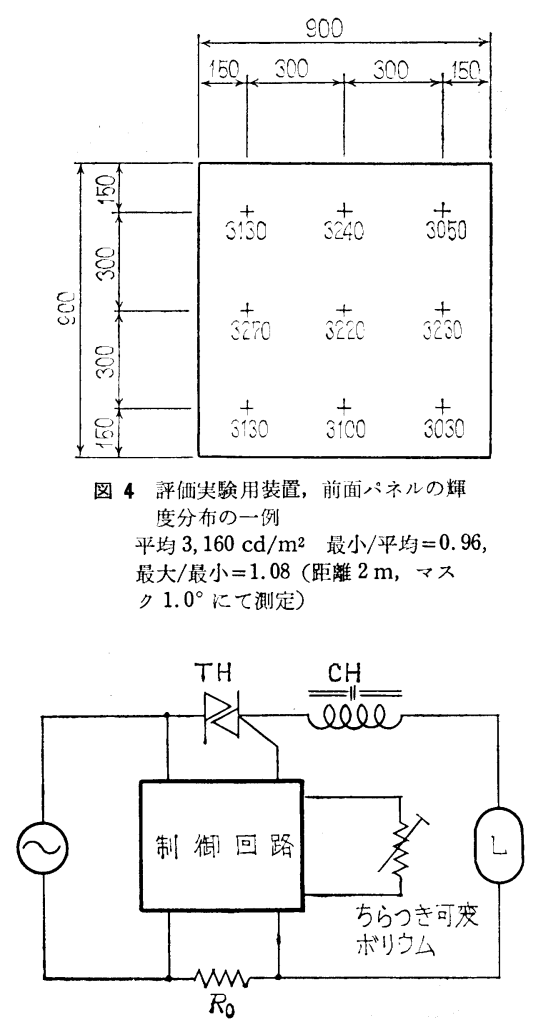

図75 ららつき可変装圆の基本回路

点灯装置拉よびもらつき可变装置は, 図 5 に示するのを製作 して用いた.これは半導体スイッチング素子（トライアック： TH）にて，電源電生の正負サイクルごとに導通時点を変えるこ とができるもので，ちらつき可変用ボリウムを動かすことによ
り，平均出力を注とんど変化させることなく，圀2 亿示すように ちらつきを可変させることができる，可変緟眍はひずみ波フリッ 力值で 0 〜約 18 である.

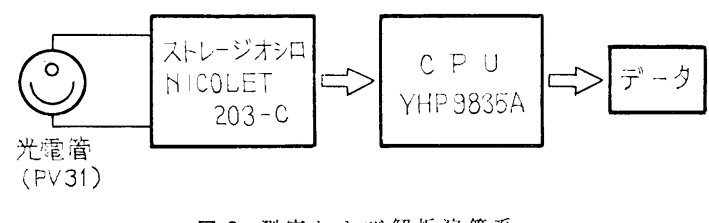

図 6 测定抢よび解析演算采

発光波形の測定就よび解析演算系は 図 6 に示す系統とした. 光電管による測光は, 図 3 に示す装置の背面に小孔を設け, 光源 の直接光とした. これは前面パネルからではパネル面の輝度の低 下に伴いストレージオシロの感度を上げなければならず，测定䛊 差が生じるためである、サンプリングは 1 調期を忘用電源の 2 倍 $(1 / 25 \mathrm{sec}$ ，または $1 / 30 \mathrm{sec})$ 飞設定し，その区間を 200 分割して いる.ひずみ波フリッカ值は, この 200 個/周期のデータをスト レージオシロから直接パソコンに取り込及解析演算させ求める.

\section{2 方法}

実験 I は次に示す手順に従って両眼視で行なった。

（1）被験者は椧査光を与えるパネル（図 3 ）の前に座り, 約 1 分間その輝度に順応する.

(2) 練習として検査光のちらつきを最大から最小まで可変し, ららつきが図 7 のカテゴリーに分けられることを示す.それが 十分認識できるまで練習する。

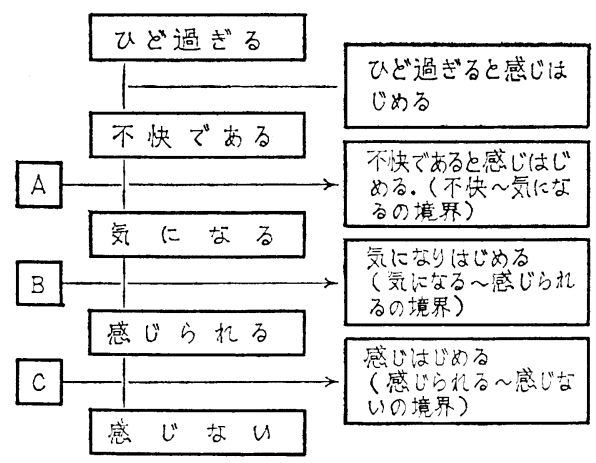

图 7 実験のカテゴリー

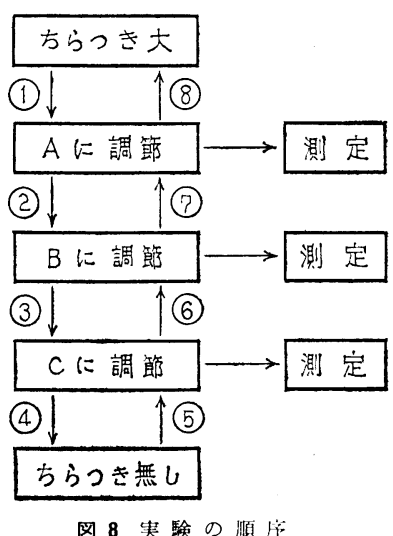

（3）図８に示す順序を1サイクルとして，各カテゴリーであ ると感じるまで被験者自身にっらつきの程度を調節させ，そのと きのひずみ波フリッカ值を測定する.

（4）検査光の輝度をかえ，同様の手順で为験を行なった，検查 
光の媈度は次の 7 段階とした. 検查光 (パネル面平均) 辉度 ; $3160,1850,973,457,263,156,96.0\left(\mathrm{~cd} / \mathrm{m}^{2}\right)$.

実験環境は検査光以外の光が 無視できる暗室とし，電源は 50 $\mathrm{Hz} 200 \mathrm{~V}$ とした. 被験者は図 9 に示寸構成の男女 31 名とし た。

\begin{tabular}{|c|c|c|}
\hline 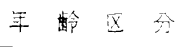 & $\stackrel{P}{\mapsto}, \ldots$ & $10, \ldots$ \\
\hline 20 歳京満 & 1 & \\
\hline $20 \sim 30$ 碳 & & \\
\hline $30 \sim 40$ 壶 & & \\
\hline $40 \sim 50$ 齐 & & 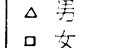 \\
\hline 50 歲以上 & & ・登計 \\
\hline
\end{tabular}

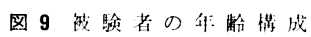

実験 II , 電源周波数 $60 \mathrm{~Hz}$ 時のひずみ波フリッカ值と感覚量 との関係を予想することを目的に，実験 I と同様の垁験を行なっ た.

ここでは被験者を 3 名（男性34歳, 35藏, 39歳) 選定し, 検査 光輝度 2 段階 $\left(1850,457 \mathrm{~cd} / \mathrm{m}^{2}\right)$ について, $50 \mathrm{~Hz}$ の場合之 60 $\mathrm{Hz}$ の場合とを各々実験サイクル（図 8 ）で2サイクル行ならも のとした.

これにより同じカテゴリーとする $50 \mathrm{~Hz}$ ，拉よび $60 \mathrm{~Hz}$ のひず み波フリッカ値の相関をとり $60 \mathrm{~Hz}$ 時の感覚量を推定する.

\section{4. 結果}

\section{1 データの分布}

尖験 Iによって得られたデータは，ひずみ波フリッカ值のどの ような間隔（等差級数的, 等比級数的その他）に対して正規分布 するかが重要である. 検查光輝度（７段階）とカテゴリー（３段 階）の計 21 種類について，等差級数尺度と等比級数 $(\log )$ 尺度 の 2 万法で整理を行なった. 図 10 は検査光輝度 $973 \mathrm{~cd} / \mathrm{m}^{2}$, カ テゴリーAの場合について「カテゴリーを満足する確率分布」で 示した一例であり，等比級数 $(\log )$ 尺度に対して正規分布をし ていると見なした法らが適切であることがわかる.な打標準偏差 は計21種類の分布に刘して $\log$ 值で $0.117 〜 0.288$ の間となった。

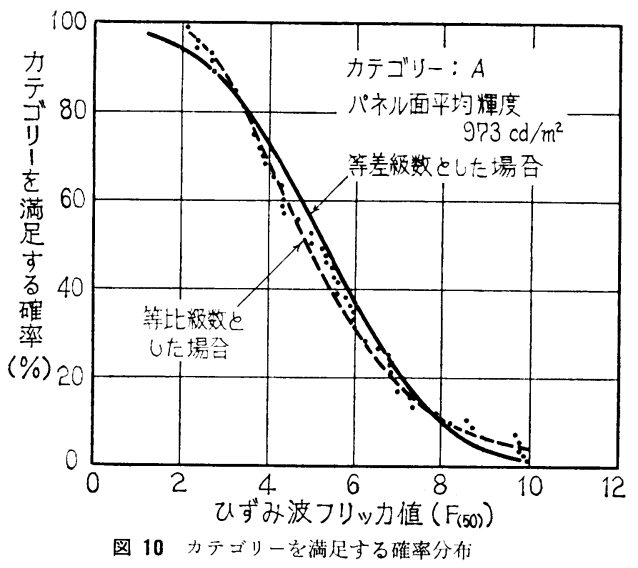

\section{2 険查光輝度との相関}

实験 I のデータは, 各カテゴリーとも検査光の輝度 (パネル面 平均輝度）が高くなるに伴い，ひずみ波フリッカ值は小さくな る.

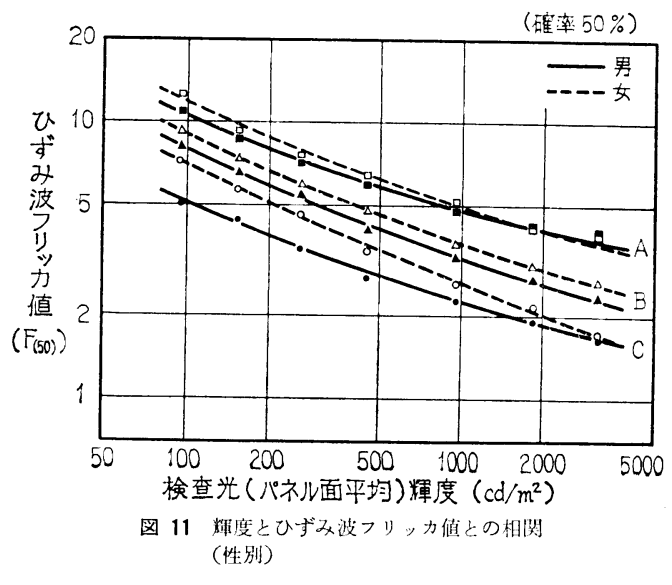

図 11 は，三つのカテゴリーについて検査光の輝度に刘するひ ずみ波フリッカ佰の平均値（確摔50\%）を性別ごとにプロットレ たものである：これより女性のほうが男性よりる，ちらつきを感 じにくい傾向があると受计止めることもできるが，年桧層の差や データ数からして明らかに羛があるとはいいがたい

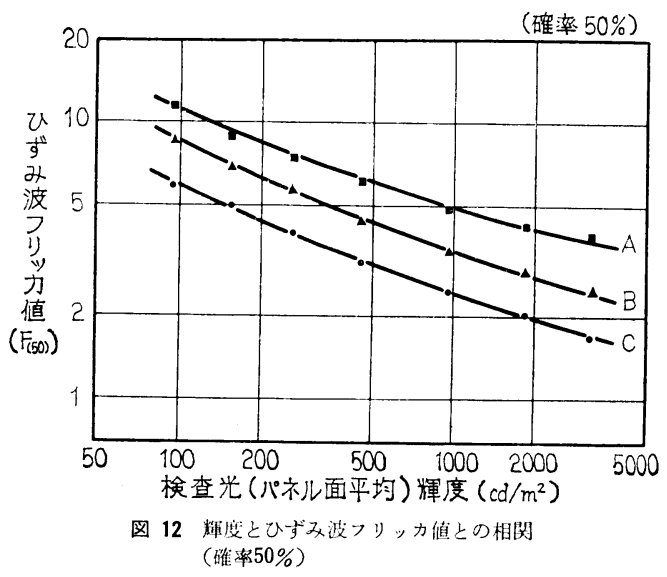

図 12 拈よび図 13 は被験者全体について集計したもので，各 カテゴリーとする確率が50\%と75\%である。確率 $75 \%$ とは，この ときのひずみ波フリッカ值であれば，少なくとも $75 \%$ の人がその カテゴリーを満足することを示す.

検査光の輝度とひずみ波フリッカ值との相関は，(6)式を一般式 とした場合に非常に良くあてはまる。

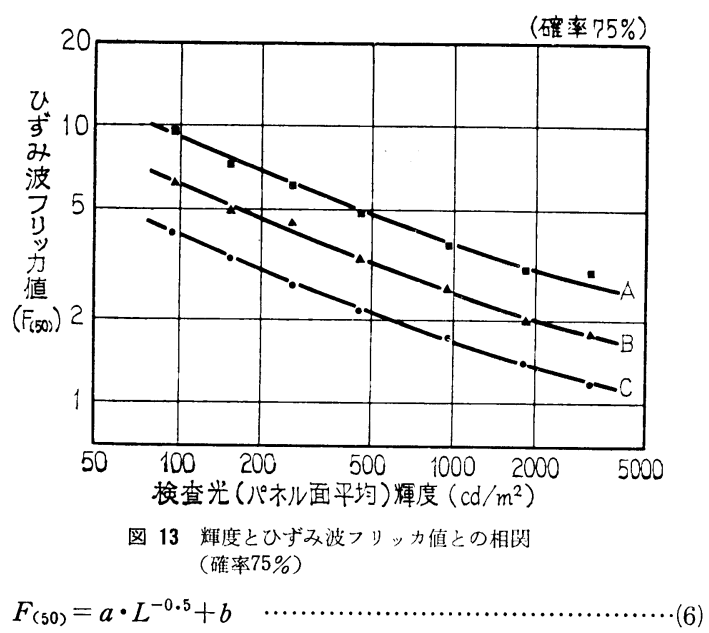

ただし， $F_{(50)}: 50 \mathrm{~Hz}$ のひずみ波フリッカ値， $L$ ：検査光の 輝度 (パネル面平均輝度), $a, b:$ 实験定数.

表 1 は， $L$ を $\mathrm{cd} / \mathrm{m}^{2}$ としたときの実験定数 $a ， b$ 抢よび相関 
表 1 実験定数之相関係数

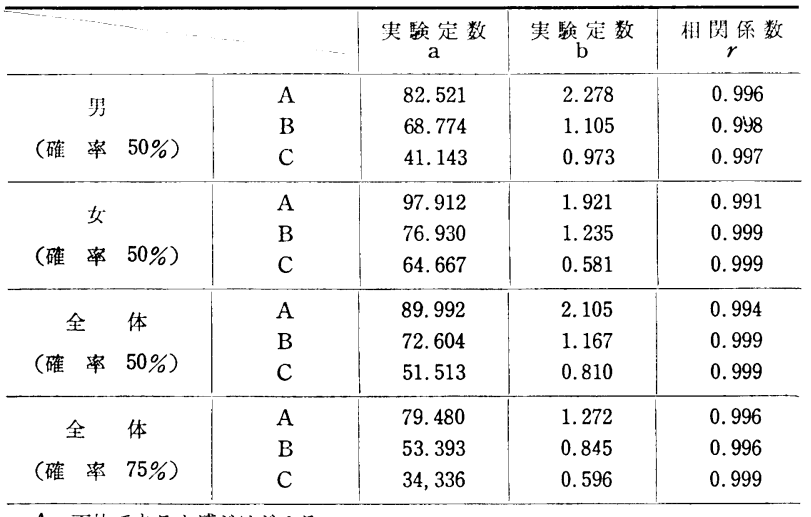

$\mathrm{A}$ : 不快であると感じはじめる

$\mathrm{B}:$ 気になりはじめる

$\mathrm{C}:$ 感じはじめる

係数 $(r) *$ を最小自乘法にて求めた值である. 図11〜図13に示す 回帰曲線は(6)式抢よび表 1 に基ついている.

実験状態では, 検查光の輝度が被験者の順応輝度に注注等しい と考えられる.すなわち本実験の輝度範团において, 順応輝度が 上昇するに伴って，小さなひずみ波フリッカ值まで識別できるこ とが明らかになった。

一般に順応輝度が高くなるに伴い視機能が问上すること，お上 び検查光の輝度が高くなるにつれて, CFFが上䊬することから推 定すれば，ひずみ波フリッカ值でちらつきの大小を表わし得ると 考允られる、すなわち，ひずみ波フリッカ值が小さくなる汪どち らつきは知觉されにくくなるといえる。

\section{3 カテゴリーの尺度化（等間隔性）}

実験カテゴリー（図 7) は序数尺度で饬るので，等間隔性とし

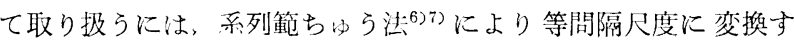
る必要がある。
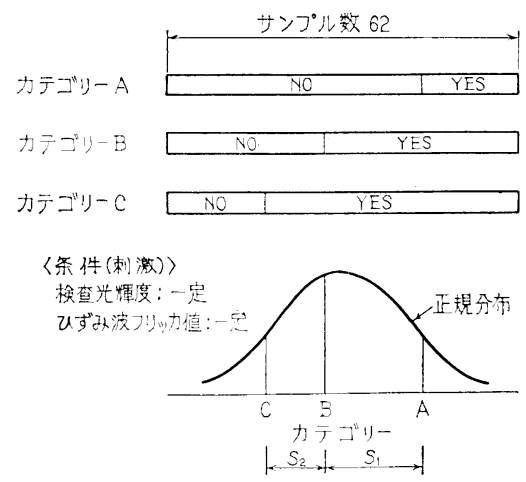

図14 カテゴリーの尺度モデル

実験 I は，カテゴリー3 段階について実施したものであるの で，図 14 に示す等間隔尺度への変換モデル図に従って行なっ た. 実験データは，表 2 に示すように刺激（検查光輝度，ひず み波フリッカ值）を一定としたときのカテゴリーに対するデータ 分布に処理し，それを確率に変換した．次にカテゴリーA， B，

\footnotetext{
* 相関係数 $(r)$ は, 変量 $x, y$ 間の相関関係を表わするので次式で求まる. $r$

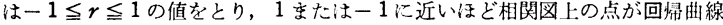
上のまわりに集中していることを示し， $r=0$ で相関がないことを示す。$$
r=\frac{S_{x y}}{\sqrt{S_{x x} \cdot S_{y y}}}
$$

ただし， $S_{x x}=\sum x^{2}-\frac{\left(\sum x\right)^{2}}{n}, S_{y y}=\sum y^{2}-\frac{\left(\sum y\right)^{2}}{n}, S_{x y}=\Sigma_{y y}-\frac{\sum x \cdot \Sigma_{y}}{n}$, $n:$ サンプル数
}

表 2 カテゴリーに対するデータ分布（一例）

\begin{tabular}{|c|c|c|c|c|c|c|}
\hline 㛟查光輝度 & & $<2$ & $<4$ & $<6$ & $<8$ & $<10$ \\
\hline \multirow{4}{*}{$1,850 \mathrm{~cd} / \mathrm{m}^{2}$} & A & 6 & 25 & 47 & 56 & 62 \\
\hline & $\mathrm{B}$ & 15 & 45 & 57 & 62 & - \\
\hline & $\mathrm{C}$ & 28 & 54 & 61 & - & - \\
\hline & 他 & 34 & 8 & 1 & 0 & 0 \\
\hline \multirow{4}{*}{$457 \mathrm{~cd} / \mathrm{m}^{2}$} & A & 0 & 8 & 27 & 44 & 61 \\
\hline & B & 2 & 24 & 48 & 57 & 62 \\
\hline & $\mathrm{C}$ & 12 & 39 & 54 & 62 & - \\
\hline & 他 & 50 & 23 & 8 & 0 & 0 \\
\hline \multirow{4}{*}{$156 \mathrm{~cd} / \mathrm{m}^{2}$} & A & 0 & 0 & 9 & 15 & 46 \\
\hline & B & 2 & 4 & 20 & 34 & 57 \\
\hline & $\mathrm{C}$ & 5 & 18 & 34 & 45 & 62 \\
\hline & 他 & 57 & 44 & 28 & 17 & 0 \\
\hline
\end{tabular}

供考 (1) 刺激が一定のとき，各カテゴリーを满足する個数を示寸（因 14 に示 すYESの個数)

（2）他の項は，カテゴリーCを满足しない個数を示す. (図 14 に示すカテ ゴリーCのNOの個数)

C間の距離を $S_{1}$ および $S_{2}$ としたとき，夹験データが正規分布す るとの仮定に基づき, 距離 $S_{1}, S_{2}$ を求め次の此を得た。

$$
S_{1}: S_{2}=1.00: 0.94
$$

これより,カテゴリー A, B，Cの間隔は，汇等間隔である

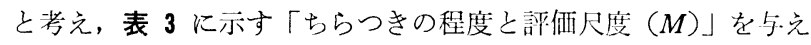
た.

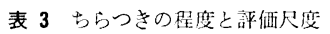

\begin{tabular}{c|l}
\hline 評 価尺 度 & \multicolumn{1}{|c}{ ちらつきの程 度 } \\
\hline- & 感じない \\
2 & 感じじめる \\
- & 感じられる \\
4 & 気になりはじめる \\
- & 気になる \\
6 & 不快であると感じはじめる \\
- & 不快である \\
- & ひど過ぎると感じはじめる \\
- & ひと過ぎる \\
\hline
\end{tabular}

\section{4 評価尺度との相関}

検査光の輝度を一定としたときに，ちらつき評価尺度（表 3 ） とひずみ波フリッカ值との相関の一例を図 15 に示寸.

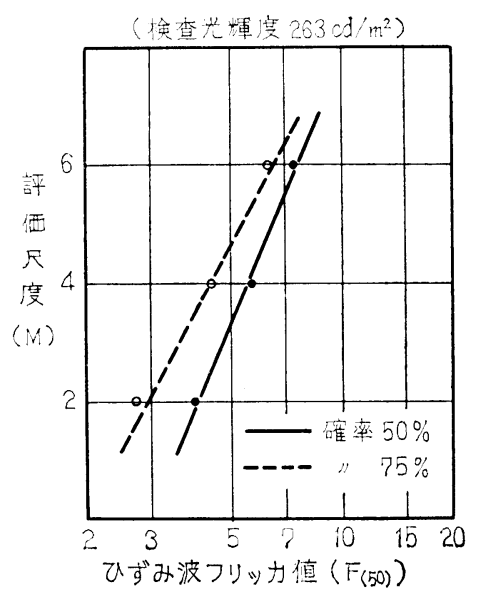

图 15 評価尺度 $(M)$ との相関 $(50 \mathrm{~Hz})$

これは，(7)式を一般式としたときに非常に良い相関関係が得ら れた。

$$
M=k_{1} \cdot \log \left(F_{(50)}\right)+k_{2}
$$

ただし， $M$ ：ちらつき䛠価尺度， $F_{(50)}: 50 \mathrm{~Hz}$ ひずみ波フリッ 
力值, $k_{1}, k_{2}$ : 実験定数

図 15 の实験定数之相関係数は，確摔 $50 \%$ の易合で $k_{1}=14.682$, $k_{2}=-6.994, r=0.996$, 確率 $75 \%$ の埸合で $k_{1}=10.902, k_{2}=-$ 2.782, $r=0.992$ となる (最小自乘法).

この式は Ferry-Porter の法則，あるいは Granit-Harper の 法則の一般式と们じであり，ここでは「ひずみ波フリッカ值が增 すにつれてちらつき評価尺度が增し，ちらつきが大きくなる」と いえる.すなわち，本実験に用いた輝度籁囲に扐いては，光源の 発光波形のひずみに起因するちらつきの程度を表才すのにひずみ 波フリッカ值が適用できることが判明した。

\section{4. $550 \mathrm{~Hz}$ と $60 \mathrm{~Hz}$ の相関}

実験 Iは， $50 \mathrm{~Hz}$ のひずみ波フリッカ值と $60 \mathrm{~Hz}$ のひずみ波 リッカ值との相関を求め, $50 \mathrm{~Hz}$ 時の感覚量と等価となる $60 \mathrm{~Hz}$ のてずみ波フリッカ值を推定することを目的に実施した.このと きの発光波形は時間軸が相違する以外は活涪相似形であった。

得られたデー夕は, 各被験者について, カテゴリー, 検査光輝 度拈よび周波数ごとに平均値に加工した．図 16 はこれをプロッ トし最小自乗法にて相関を求めたものである.

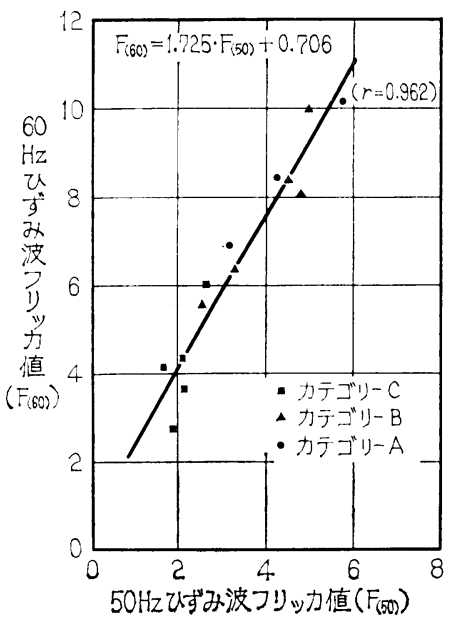

图 $1650 \mathrm{~Hz}$ と $60 \mathrm{Hs}$ との相関

一般にちらつきは，周波数が高くなるに伴い知覚されにくくな る. 本結果も同様の傾向を示し，(8)式に示すようにほ注直線相関 $(r=0.962)$ が得られた。

$F_{(60)}=1.725 F_{(50)}+0.706$

ただし， $F_{(60)}: 60 \mathrm{~Hz}$ ひずみ波フリッカ値

$F_{(50)}: 50 \mathrm{~Hz}$ ひずみ波フリッカ值

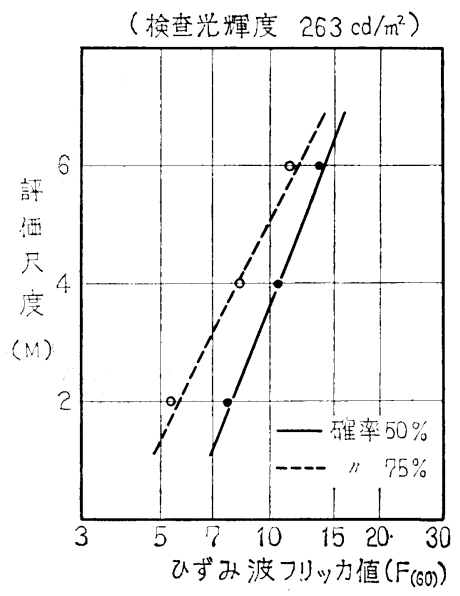

図 17 評価尺度 $(M)$ との相関 $(60 \mathrm{~Hz})$ (50 $\mathrm{Hz}$ からの推定)
このことは，(8)式にて $60 \mathrm{~Hz}$ に拈けるちらつきの感覚量をほぼ 予想することができるものと考兄られる。

図 17 は, 図15の $50 \mathrm{~Hz}$ 時のデータから(8)式を用いて，60 Hz のひずみ波フリッカ低と評㑛大度との関倸を手想したものであ る.このときの回师式は(7)式と同様に(9)，(10)式で表わせる.

$$
\begin{array}{r}
M=15.805 \log \left(F_{(60)}\right)-12.022 \\
\quad(\text { 確率50\%, } \quad r=0.996) \\
M=12.066 \log \left(F_{(60)}\right)-6.878 \\
\quad(\text { 確率 } 75 \%, \quad r=0.993)
\end{array}
$$

$50 \mathrm{~Hz}$ 時の感覚量と等価となる $60 \mathrm{~Hz}$ のひずみ波フリッカ值 は, $50 \mathrm{~Hz}$ 時の值の約1. 7 1. 8倍と推定できる.

\section{5. 考察}

発光波形のひずみに起因するちらつき評価を行なう主要目的 は，実際の施設において種々さまざまな発光波形を有する光源を 使用する場合に，ちらつきをどの程度まで扣さえれば問題がない かを予測することである。すなわち本実験結果から主に次に示す 2 点の疑問が生じるものと思われる.

(1) 実験状態と実際の施設との差異はどうであるか.

（2）発光波形が図 2 に示寸ものよりも複雑な場合にも，ひずみ 波フリッカ值と感覚量との関係が一定に保たれるか.

\section{1 実験状態と実際の施設との差異}

図 2 に示すような発光波形の光源が，実際の施設で使用された と仮定した場合，垁験状態との相違点は主に次のようである。

\section{《実験 状態》}

検查光輝度々順応輝度とがほぼ等しく, 検査光が被験者の視野 の大半を占めている.

\section{《実際施設》}

検查光辉度（光源，照明器具や被照面）と順応輝度が異なるこ とが多く，一般に順応輝度のほうが低い場合が多いまた検查光 は視野の一部分にしかなく，その位置が種々さまざまである。

一般に明暗の知覚は，そのときの目の感度を代表する順沁輝度 が高くなるに伴い小さな刘比まで識別される。また CFF の研究 や本実駼結果からも明らかなよらに，順応輝度が高くなるに伴い 小さなちらつきまで知覚されるようになる。

一方, $\mathrm{CFF}$ の性質として $100 \mathrm{~cd} / \mathrm{m}^{2}$ 以上の刺激に対しては, 視野の中心よりも周辺部の活うがちらつきを感じやすいこと，刺 激面が大きくなるに伴い，ちらつきを感じやすいことなどが明ら かにされている4).

したがって，実際の施設よりも実験状態のほらが一般的にいっ てちらつきを感じやすい状況下にあるといえる，すなわも，ひず み波フリッカ值が等しければ, 実際の施設のほらが知覚されにく いと予想できる.

\section{2 複雑なひずみ波形における差異}

われわれが提案した評価法の基本式は(3)式である.すなわち, どのように発光波形がひずんでいたとしても,フーリエ級数に展 開できる.CFF の研究や本実験結果からも明らかなよらに，ち らつき知覚は低周波であるほど知覚が容易である．また，腰原 $ら^{3)}$ も発光波形の低周波成分が，ちらつきに招いて重要な因子で あることを報告している.したがって複雑なひずみ波形に対して は，測定および解析系の周期を長く設定し，その周期を基本とし たときの第 $N$ 次高調波成分（ $N$ ：整数）まで解析し, 各低周波成 分（各高調波成分に相当する）のひずみ波フリッカ値を求め, 各 
トがセらつき感覚にどのように寄与するかを䂙究することによっ て評価することが可能である.たと竞ば電源周波数が $50 \mathrm{~Hz}$ の場 合には，このような方法により $10 \mathrm{~Hz}, 20 \sim 100 \mathrm{~Hz}$ といった备成 分を抽出与ればよいことになる. しかしながらデータの解析が非 常に複雑になるばかりでなく，その必贾性にも疑閒の余地があ る.

したがって，既存の光源の発光波形がひずむ要因を考察し，ど の周波数成分が重要であるかを検討するのが夷用的であろう.

光源の発光波形がひずも原因は，次の 2 点が大きな要因である と推測できる。

(1) 供給電源に起因するもの

(2) 光源の発光機構に起因するもの

ここで光源側に問題がないものとすれば，発光波形のひずみは 供給電源の周波数的要因によって主に決定づけられる. 害用上の 光源に対するちらつき知覚は, 本実駼結果からも明らかなように $100 \mathrm{~Hz}$ の規則正しい発光周波数に対しては，まず知覚されない. したがって供給電源側の变動による要因は, 発光周波数の $1 / N$ $(N$ : 整数) の周波数的変動として発光波形に現われることにな る.

次に光源の発光機構に起因する要因を考察すれば，それは主に 二つの電極に起因するもの, 临光現象に起因するものなどが考兄 られる.しかしこれらは供給電源側に問題がないものとすれば, 少なくとも電源周波数に從って規則正しくひずもはずである.す なわち蛍光波形は, 電源周波数の第 $N$ 次高調波 $(N$ : 整数) まで が重嘼しなものとなり，電源周波数よりも低い周波数成分が生じ る余地が少ないといえる.

電源側と光源側を複合して考喤た場合には，非常に複雑にひず んだ発光波形であったとしても，ちらつき知覚に寄与する低周波 成分は，その大部分が䇏用電源周波数成分であると推定できる.

以上より，われわれは実用上のちらつき評価に関しては，商用 周波数成分の抽出だけで十分対応可能であり, 評㑛值がほ济既存 の光源に適用できるものと予測している.

\section{6. ま め}

われわれ性光源発光波形を一種のひずみ波であると考克，その 商用電源周波数成分の全体に上好る割合によって，光源のちらつ き評価ができることを見いだした，その主要な結諭を次に示す，

(1) 従来の評洒法（フリッカインデックスやパーセントフリッ カ）で評価できなかった発光波形のひずみに起因するちらつき を，ひずみ波フリッカ值（(4)式）を考案することにより評価でき ることが判明した.

（2）ひずみ波フリッカ值が大きくなるに伴い，ちらつきの感覚 量が增加する．評洒尺度をパラィータとしたときのひずみ波フリ ッ力値之検查光輝度との相関, 検査光輝度をパラメータとしたと きのひずみ波フリッカ值と評価尺度との相関を示し，これらの回 㷌式が(6)式，(7)式で与えられることを示した。

(3) $50 \mathrm{~Hz}$ 時と $60 \mathrm{~Hz}$ 時に执いて評俩尺度が等価となる関係 は（8)式で与えることができることを見いだした。

な技考察の 5.2 項で複雑なひず久波形に対しても，ひずみ波つ リッカ值上感觉量との関係が，ほぼ一定に保たれるとの予測を行 なった. この問題に対する検証は今後の研究課題としたい。

\section{参 考 文 献}

(1) たとえば, IES LIGHTING HANDBOOK 1981 Reberence Valume 8-30

（2）腰原，伊藤，杉浦：炤55照学:会全国大会30

（3）同上 : 昭56照学会全国大会33

（4）たとえば，感覚十知覚ハンドブック 誠信書房（昭44）

(5) 電気学会大学講座, 電気回路論 電気学会

（6） J . P.ギルホード：精神测定法 培風館

（7）田中良久：心理学的測定法 東京大学出版会

（受付1985年 2 月 21 日） 